\title{
BRIEF HISTORY OF GENERAL LANGUAGES AND LANGUAGE POLICIES IN COLONIAL BRAZIL
}

\author{
Samuel Figueira-Cardoso* \& Alexandre da Silva Borges ${ }^{* *}$
}

\begin{abstract}
Brazil is a multilingual and multicultural country and was so even before the Europeans arrived in the territory. Over the centuries, contact and conflict between European and African languages with indigenous languages have influenced the variety of Portuguese spoken in the country since the $16^{\text {th }}$ century. In this paper ${ }^{1}$, we present an overview of Brazil's languages, referring to the so-called general languages and the language policies in favor of the Portuguese language in the period. To this end, we resort to: the contributions of scholars who investigate the use of language in society or "social history of language" (Burke 2002, Freire 2003); some concepts derived from the field of language policy; notions of heritage and indigenous culture. It is shown that the policies of colonization were harmful to linguistic diversity, as in the case of the Nheengatu language spoken until today in the North of the country, due to the continuous resistance of the speakers of the language.
\end{abstract}

Keywords: general languages, language policy, multilingualism, Amazon region

\section{Introduction}

Upon arriving on the southern coast of the American continent, in the territory known today as Brazil, the Portuguese navigators found linguistic diversity manifested through the hundreds of languages spoken by the people who inhabited the lands at the time of the expedition of Pedro Álvares Cabral. The complex set of civilizations in Brazil, resulting from the plurality of indigenous communities and individual differences, reflected a cultural and linguistic richness, which would be subjugated to the Portuguese language.

Pero Vaz de Caminha's letter, intended to describe the Portuguese arrival in the so-called "found" lands (see Fausto 2002: 9), reports that the native inhabitants were good-looking and showed curiosity in their first contact with the Europeans. This indicates a tendency towards contact, in spite of the language barrier. In this regard, from the perspective of hermeneutics based on the studies of the Imaginary, we can speak of the "pre-linguistic" factor, that is, a system that favors contact between subjects of different languages through context and the communions thereby made possible. There is, therefore, an underlying affinity.

According to Ortiz-Osés (2003: 98), we can also infer an "affective context and implicit communication, as well as a certain complicity, kindness or consent." However, over time, it became obvious that the cultural domination based on language was structurally organized on the Brazilian territory, then still part of the Portuguese colonial empire. For Burke (2002: 135), language "is, like consumption, a means used by some social groups to distinguish themselves from others". In addition to differentiation,

\footnotetext{
${ }^{*}$ Uniwersytet Warszawski, Wydział Neofilologii, Instytut Studiów Iberyjskich i Iberoamerykańskich, Zakład Brazylianistiky, s.figueira-ca2@uw.edu.pl.

${ }^{* *}$ Universidade Federal de Pelotas, alexandreborgesh@gmail.com.

${ }^{1}$ A preliminary version of the paper was first published as Figueira-Cardoso \& da Silva Borges (2020).

Bucharest Working Papers in Linguistics XXIII, 1, 79-93, e-ISSN 2392-8093, ISSN-L 2069-9239 DOI: 10.31178/BWPL.23.1.4
} 
however, language turned out to be the prime cause conducive to the centralization of the power of Portugal over the conquered territory.

The official colonization in Brazil began in 1532 when French invasions threatened the Portuguese Crown. Different historians (e.g. Prado Jr 2008, Cotrim 2005, Fausto 2002) divide the colonial period into different phases. In what follows, we highlight three periods. The first refers one is covers the arrival of the Europeans and the process of bartering with the natives - that is, the first contacts and the demand for wood, supplied by Brazil. In exchange for trinkets, the natives took the Portuguese to the natural resources, besides introducing them to other tribes. This period provides unique insights into the rich array of indigenous languages spoken at the time.

The second period, from the $16^{\text {th }}$ century onwards, witnesses the organization of the so-called "hereditary captaincies", from the donation to the grantees of extensive tracts of land for settlement, extraction of resources and distribution of wealth for Portugal. Prado Jr (2008) specifies that between 1530 and 1640 there was an effective occupation of Brazilian lands. According to Fausto (2002: 11) and other historians, the captaincies "failed", given the numerous difficulties - among them, the language barrier, the scarcity of translators or written materials in the Portuguese language, addressing the issue of a means of communication between settlers and natives. The third period, from 1770 to 1808 , the heyday of the colony, corresponds to the centralization of the colonial administration of Brazil.

To understand the course of the implantation of the Portuguese language in Brazil, some essential characteristics of the colonization process should first be mentioned, such as the extermination of the autochthonous population and massive colonization by the Portuguese from the $16^{\text {th }}$ to the $19^{\text {th }}$ century (Lucchesi 2012). The first settlers "brought an archaic Portuguese language, tinged with regional differences [...] that soon faded into the great American melting pot of linguistic interaction" (de Castilho 1962: 10). More recently, de Castilho (2008) points out that, although the Portuguese settlers, especially at the beginning of colonization, came from all regions of the metropolis, most of them must have hailed from the south. Evidence in support of this conclusion is provided by several phonetic and phonological characteristics of Brazilian Portuguese:

(i) absolute occurrence of pre-dorsodental [s], typical of southern Portugal, and the absence of apico-alveolar [s], typical of northern Portugal.

(ii) monophthongization of the diphthong [ey], as in primeiro 'first', phonetically realized as [ây] in the North;

(iii) maintenance of the distinction between $/ \mathrm{p} /$ and $/ \mathrm{b} /$, which are alternating pronunciations in the North, with both varrer and barrer 'to sweep' occurring.

Contact with the native languages of the African slaves led to the emergence of the Brazilian variety of Portuguese, different from European Portuguese. Furthermore, some authors (e.g. Bagno 2018) argue that Brazilian Portuguese is in fact another language, rather than merely a variety of Portuguese. 


\section{The general languages in Brazil: A brief historical journey}

With the emergence of villages on the coast of "Terra Brasis" or "Brasilis," contact between indigenous languages and Portuguese began. Among the hundreds of indigenous languages spoken at the time, one of them gained the Portuguese settlers and missionaries' interest, who later called it the general language. At first, this language, in the multilingual and multi-ethnic territory, served to unify, control, and expand the Portuguese Crown domains. This linguistic contact process favored the disappearance of many indigenous languages through the evangelization/catechization, itself an integral part of the policy of expansion. Fausto (2002: 10-11) explains the relationship between the Portuguese Crown and the Catholic Church:

The Portuguese state had a position of somewhat dominance over the Church. It was a system called patronage. The patronage was a kind of unwritten understanding between the Portuguese Crown and the Church, by which the Church had spiritual powers, but at the same time, the Crown had control over the appointment of ecclesiastics and was also responsible for paying the clergy, the priests who came to Brazil - not the religious orders, but the so-called secular clergy. The Church was dedicated to the salvation of souls, to the conversion of Indigenous to Catholicism. Thus, it was necessary to organize the villages, teach the Catholic religion, and not destroy the indigenous population. Nevertheless, there were many clashes between the Church and the settlers in Brazil because the settlers had another interest: exploiting the indigenous work.

From this perspective, Raymundo (1998: 43) notes that the "Order of Jesuits is a product of mutual interest between the Portuguese Crown and the Papacy. It is useful to both to the Church and the emerging state. The two intend to expand the world, defend the new frontiers, join forces, integrate lay and Christian interests, organize the work in the New World by the force of the law-king-faith unity". However, this was an authoritarian and conservative project aiming at catechizing the indigenous population as well as the imposition of the European language and customs, neglecting the linguistic and cultural diversity of the indigenous communities. In this respect, colonial unity and centralization owe a great deal to the Jesuits' attempt at generating social transformation based on three factors: language, religion, and culture.

The actions of the Jesuit companies, for example, were intended to convert the Indians to the Christian faith, which presupposed catechesis and teaching: reading and writing, not only in Portuguese but also in the native language of interest in that context, for example, a language of Tupi origin, which later became known as lingual geral 'general language'. Over centuries, the general language, like every living language, underwent change and variation. Its expansion was considered a danger to the Portuguese kingdom's interests, which imposed measures in favor of the Portuguese language, such as the decree ${ }^{2}$ in the so-called Pombaline era in the $18^{\text {th }}$ century.

\footnotetext{
${ }^{2}$ In this case, we refer to the Directory of the Indians, documents elaborated in 1755, published in 1757 , written by Pombal, consisting of 95 articles. The content of the document can be consulted in the following page (https://www.nacaomestica.org/diretorio_dos_indios.htm).
} 
Historical research, in Brazil, point to a diversity of tribes, even if Tupi-Guarani stands out among them as a "great nation". Therefore, it is worth remembering that there were many others, such as the Aimorés - tribes that "sometimes lived together and sometimes fought" (Fausto 2002: 10). These conflicts arose from the diversity of customs and languages among peoples, even among the Tupi-Guarani. Linguists mention the Amazonian General Language and the São Paulo General Language as the most prestigious among the other languages, which over time began to be imposed as an instrument of communication between the indigenous groups, the Church, and the settlers. More recent studies indicate that a general language was also developed in Southern Bahia (Argolo 2016).

Ayron Rodrigues was the first linguist to suggest a concise definition of the term "general language," Rodrigues (1996) considers, besides the São Paulo General Language and the Amazonian General Language, which he calls guarani criollo 'Creole Guarani, ${ }^{3}$ which emerged in the area between the rivers Paraná and Paraguay, highlighting the part played by the Spanish colonizers, that is, by the Spanish language in the formation of this variety (Rodrigues 1986, 1996). The author also expatiates on the general languages as a product of the linguistic contact and explains why there were no general languages established from Rio de Janeiro to Piauí. The Jesuit missionaries had to learn the general language to carry out the plans of the Church in the Colony. Rodrigues also maintains that the expression "general language" was consolidated in Brazil in the $17^{\text {th }}$ and $18^{\text {th }}$ centuries, when, in São Paulo as well as in Maranhão and Pará, the languages of indigenous origin, spoken by the inhabitants of the two provinces, started to be called by this term.

It would be, then, a language of Mamelucos, which emerged in a context of miscegenation between the European settlers and the Tupi-Guarani (namely the Tupi in São Paulo and the Tupinambás in Maranhão and Pará), in a practice called cunhadismo (from Portuguese cunhado 'brother-in-law'). During the colonial period, to this social context was added a contingent of African origin and contingents of several other indigenous peoples, generally as slaves or as the so-called indios de missão 'mission Indians' respectively (Rodrigues 1996). Ribeiro (1995: 82-83) explains that the cunhadismo consisted of the following practice:

The function of the cunhadismo in its new civilizing insertion was to bring out the numerous layers of mestizo people who effectively occupied Brazil. [...] Based on the cunhadismo, breeds of mestizo people are established in the centers where castaways and exiles settled. First, together with the Indians in the villages, when they adopt their customs, living like them, piercing their lips and ears, and even participating in anthropophagic ceremonies, eating people. Then they learn the language and become familiar with the indigenous culture. Many liked it so much, that they let themselves stay in the good life of Indians, friendly and helpful. Others formed units separated from the villages, composed of them, their multiple Indian women, their numerous children, always in contact with their kin (Ribeiro 1995: 82-83).

\footnotetext{
${ }^{3}$ Also known as guarani paraguayo 'Paraguayan Guarani’.
} 
Another practice typical of cunhadismo was to give a settler an indigenous woman as his wife. This custom favored miscegenation and the formation of the Brazilian people, since as soon as the foreigner accepted the indigenous woman as his wife, family ties were automatically established, and thus alliances with all members of the indigenous community.

Other researchers on the subject have put forth different versions of the concept of general language defined in the most varied ways: "1) it is Tupinambá itself; 2) it is a language of intercession, the result of the learning of Tupi dialects by white men; 3 ) it is Tupi simplified by the Jesuits; and 4) it is a language of Tupi-Guarani origin, which emerged in the use by the Mamelucos" (Argolo 2016: 10). We will not go deeper into the discussion of the concept of general language, and we will adopt a broader notion of the term, proposed by Lagorio (2009: 310), reproduced below:

General Language refers to a region's language or a multilingual area, which serves as a vehicle for inter-ethnic communication between speakers of particular languages. One of the colonizers' first steps was to identify those languages that allowed a relative communicative range, estimating that their use would exempt them from learning and tackling minority languages.

The author adopts a more conciliatory tone. In the Amazonian context, the native language privileged by the missionaries and settlers was the Tupinambá language. The relationship between missionaries, in the process of catechism, gave rise to a parallel mythology, which is neither that of the missionary nor that of the Indigenous, explained by Navarro and Tessuto Júnior (2016: 28) when quoting Bosi (1992: 65):

The project of transposing the Catholic message into the language of the Indigenous required an effort to penetrate the other's imagination, and this was the commitment of the apostle [Anchieta]. [...]. How could we tell the Tupis, for example, the word sin, if they lacked even its notion, at least in the way that it would be understood throughout the European Middle Ages? Anchieta, in this and other extreme cases, prefers to graft the Portuguese word onto the trunk of the native language; he does the same, and with strong reason, with the word mass and the invocation to Our Lady:

Ejori, Saint Mary, xe anama rausubá

Come, Saint Mary, to have compassion for my family[...]

Such cases are, however, atypical. The most common is the search for some homology between the two languages, with results of unequal value:

Bishop is pa'i-guaçu, that is to say, Lord Major. Our Lady sometimes appears under the name of Tupã-sy, mother of Tupã. The kingdom of God is Tupãretama, Land of Tupã. Church, coherently, is Tupãoka, home of Tupã. [...]

The new representation of the sacred thus produced was no longer either Christian theology or Tupi belief, but a third symbolic sphere, a kind of parallel mythology that only the colonial situation had made possible 
Brazil's general languages became an instrument of the policy of expansion of the borders of the two colonies that Portugal had in America - the state of Brazil and the state of Maranhão and Grão-Pará - maintaining a very different rhythm of expansion, varying from one colony to the other.

There are indications of the existence of a general language in the South of Bahia, east coast of Brazil, as mentioned by Navarro (2012: 245-246) when quoting Lobo et al. (2006):

in 1794, officials of the Chamber and republics of Vila de Olivença requested Antônio da Costa Camelo, acting ombudsman of the District of Ilhéus, to appoint Manuel do Carmo de Jesus as Director of Indigenous peoples, claiming, as the most significant reason for this, that [he] was raised in that village and knows the general language of indigenous communities in order to know better how to teach them.

From the perspective of Brazil's linguistic social history, Argolo (2016: 20) argues that this variety of Tupi developed in a socio-historical context of language shift:

The structuring of this variety of Tupinambá, also called general language, in the colonial period took place in a sociolinguistic context similar to that of the general language of São Paulo, due to the arrival, in 1534, of the fleets of the Castilian Francisco Romero (at the behest of the Portuguese Jorge de Figueiredo Correia, to whom part of the south coast of Bahia was donated), to found the Captaincy of Ilhéus, and the Portuguese Pêro de Campos Tourinho, to found the Captaincy of Porto Seguro.

The São Paulo General Language began to be built in the $16^{\text {th }}$ century when, in 1532, Martim Afonso de Souza arrived in the then captaincy of São Vicente, today a region of the state of São Paulo, intending to begin Portuguese colonization in the area (Argolo 2016). General Language predominated in the province of Brazil, at the expense of Portuguese, until the first half of the $18^{\text {th }}$ century, when it began to lose out to the Portuguese language, due mainly to the political actions of Sebastião José de Carvalho e Melo, the Marquis of Pombal, as from 1755 with the colonization policies.

In the $17^{\text {th }}$ century - the beginning of the colonial process in the Amazon, the Portuguese settlers who arrived in Pará in 1616 found hundreds of indigenous languages, among them Tupinambá, spoken from the Salgado coastland to the Tocantins River. As put by Freire 2003: 51), "they managed to establish a reasonable level of communication with these natives because, in Pernambuco and Maranhão, where they came from, they had learned to speak the Brazilian general language". This was possible because Tupinambá, the practical mestizo language, "no longer served an indigenous society and culture, but the society and culture of the mamelucos, increasingly distant from those and closer to Portuguese culture" (Rodrigues 1996: 8), performing an initial function of the language of communication between the Portuguese and the different Tupi peoples of the region. In this context, it was necessary to urgently learn this general language, which 
was mandatory for missionary priests whose destiny was Brazil. The study of Tupi even replaced that of Greek in the training received at the Vatican - a decision supported by the directives of Pope Pius V (Freire 2003).

This policy favored the consolidation of the Amazon General Language, which is part of the Tupi-Guarani linguistic family. As already mentioned, it was a language originated from Tupinambá, under the historical circumstances of Portuguese colonization in the Amazon in the $17^{\text {th }}$ and $18^{\text {th }}$ centuries. On the banks of the Amazon river, there were more than 150 peoples, each speaking their own language. Communication was possible only with the help of interpreters from the Brazilian coast; this was called "the practice of interpreters" by Cristóbal de Acunã (Freire, 2003).

A missionary concerned about the multilingual context of the Amazon was Father Antônio Vieira. In his Epiphany sermon, the priest warns the Portuguese Crown: "If I do not understand the Gentile's language, nor does the Gentile understand mine, how can I convert him and bring him to Christ?" (Vieira 2001: 607). It was necessary to create conditions for inter-ethnic communication, useful for the Portuguese metropolis' catechization and objectives. At the beginning of the $18^{\text {th }}$ century, the Amazon population was composed of indigenous peoples, slaves, and free men integrated with the colonial system, amounting to approximately 75,000 (Freire, 2003:49). In the assessment of Father Jacinto de Carvalho, the general visitor ${ }^{4}$ of the missions in the far North, this general language became so widely used that the Portuguese themselves,

"who go from the kingdom, learn to speak the language of the natives. Their children, born in Pará and raised by indigenous nannies, ended up acquiring General as their first language because "with milk, they also drink the language," becoming Lusophone only "after going to school a few years and dealing with the Portuguese who come from Portugal". The missionary suggests that to reverse this situation, "the Portuguese sons and daughters should be prohibited from being raised by natives of the land" (Reis 1961: 495 in Freire 2003: 52).

During this period, the Amazonian General Language managed to reach all the villages and towns catechized by the Portuguese priests. The codification of the general language was left to the Jesuits through studies of its grammar, that were published in the colonial period. On the other hand, the São Paulo General Language was no longer spoken in the $19^{\text {th }}$ century and is rather poorly documented (Freire 2003).

The consolidation of Amazonian General Language as a mother tongue in the province of Grão-Pará and Maranhão was effective, given its expansion throughout the Amazon region in the $17^{\text {th }}$ and $18^{\text {th }}$ centuries, mainly in the Negro river basin, where there had been no Tupi language. From the $19^{\text {th }}$ century on, this language has been known under a new name, as explained by Couto de Magalhães, who called it Nheengatu:

In the North, it is known as nheengatu, 'the good language,' which supposes the existence of other languages, but this is the good one, either because it was the

\footnotetext{
${ }^{4}$ The functions of the general visitor were those of an inspector.
} 
language of the civilized or better of the lords of the land, or simply because they recognized it as an absolute superiority over the other Caribbean, Arucian and other dialects, or even because, unlike the others, it constituted as a trait of union between all the hordes of different languages (Freire 2003: 56).

Over the centuries, the general languages have received different names - Tupi, Ancient Tupi, Brasílica Language, General Language, Nheengatu, and others. In the context of multilingualism in Brazil, Portuguese was introduced through frequent contacts with Tupinambá and other indigenous languages, which left their mark on Brazilian Portuguese, in particular on the Portuguese spoken in the Amazon.

\section{Language policy: Some notions}

Given the goal of this article, it is essential to clarify the notion of language policy or linguistic policy in this section. Notions that, although not named with this nomenclature, have always been present in societies, that is, they are language practices, beliefs, and management that became part of scientific studies related to Sociolinguistics after World War II, a conception that will later contribute to the reflections around the examples of linguistic colonization in Brazil.

Narvaja de Arnoux (1999), states that the term "language policies" or "language policy" designate a complex field of the language sciences, which can propose lines of intervention in response to socio-political necessities. Baldauf Júnior (2004) and Ricento (2000) set the end of World War II as the historical landmark for the emergence of the discipline, with its two directions: language policy and language planning.

Schiffman (1996) expanded the concept, defining the notion of language policies as a cultural construct that is closely linked to other elements that the author called "linguistic culture", that is, a set of measures, explicit or implicit, adopted predominantly by the state but also by other social agents, to rank the languages used in a given territory. In this same perspective, Spolsky (2004) characterizes language policy as a multidimensional field, with three components: language practices, beliefs, and management. The definitions proposed by Spolsky (2004) are reproduced below

(1) language management: "the formulation and proclamation of an explicit plan or policy, usually but not necessarily written in a formal document, about language use" (Spolsky 2004: 11);

(2) language beliefs or ideology: "what people think should be done" (Spolsky 2004: 14);

(3) language practices: "what people do" (Spolsky 2004: 14).

What Spolsky (2009) called language management is called by Bonacina-Pugh (2012) a "declared language policy," i.e. one that has the consent of public institutions and is a a direct intervention in language practices and uses.

To speak of languages in the context of colonial Brazil, we borrow Mariani's (2003, 2004) notion of "linguistic colonization policy". This notion covers facts studied, 
but not named, in a process with no history of contact between peoples with different languages and memories. This contact "produces modifications in linguistic systems that had been constituted separately, causes reorganizations in the functioning of linguistic systems besides ruptures in stabilized semantic processes" (Mariani 2003: 74), through the "tension between a factual linguistic heterogeneity, and a homogeneity produced by the colonizer, materialized either in the language of the metropolis or in the indigenous language as a function of grammaticalization" (Mariani 2004: 39).

In light of the conceptual apparatus outlined above, we present in the next section some examples illustrative of factors that favored the development and "disappearance" of Brazil's general languages, highlighting some aspects of the Amazonian General Language.

\section{Language(s) and Jesuit missionaries in Amazonia}

The settlers and missionaries undertook actions for a supposed unification of the peoples, using language as a political instrument for this intention, which ultimately served to strengthen the control of the metropolis over the exploitation of the land and the evangelization of the indigenous peoples. With respect to the origin of the Amazonian General Language, Freire (2003: 51) shows that it:

begins to take shape historically when the first Portuguese settlers, who arrived in Pará in 1616, faced - among the hundreds of indigenous languages of the Amazon - the Tupinambá, spoken on the coast of Salgado to the mouth of the Tocantins River. They managed to establish a reasonable level of communication with the indigenous population because, in Pernambuco and Maranhão, where they came from, they had learned to speak the Brazilian language, a language also of Tupi origin used in catechesis by the Jesuits throughout the Brazilian coast since the $16^{\text {th }}$ century.

We can infer that by being willing to learn an indigenous language, the Portuguese established a language policy in favor of communication in an indigenous language, i.e. the Amazonian General Language. Indigenous peoples speaking different languages were brought to the villages, and there they also learned the Amazonian General Language. It was a period of bilingualism in the Amazon, as Mariani (2003: 79) corroborates:

In 1701, the Portuguese King wrote to D. João de Lencastro, saying that "many autochthones in their villages know how to read, write and count" and then stipulated as recommendations for the missionaries: "that they seek to teach the Indians in the Portuguese language; but they must first know that of the indigenous. To this end $[. .$.$] there should be masters and practitioners in the languages not only$ of the indigenous population but also of the blacks"

This language proved to be profitable to the Portuguese Crown, which accounts for its expansion from the arrival of the settlers in the region until the end of the year 1720 . 
During that period, the King of Portugal himself levelled harsh criticism at missionaries who were not as fluent as the Jesuits in that general language.

This expansion was made effective in the Royal Charter of November 30, 1689, in which Portugal granted the status of official language of the state of Maranhão and Grão-Pará to the Amazon General Language. This status even determined that the Portuguese children, living in the urban centers of the time, should speak this language. The dynamics of the process was based on the contact between two groups: on the one hand, there were the "new arrivals" in the Amazon, a group that in addition to the settlers and missionaries also included bilingual natives, these translators who spoke a Tupi-based language at the service of the expeditions; on the other hand, there were the Tubinambá, the first people they met, who also spoke a Tupi language. This context defined the guidelines of language policies in the region between the $17^{\text {th }}$ and $19^{\text {th }}$ centuries.

It is essential to point out that during this period there was a large production of language materials written by the missionaries in the province of Brazil where the general language of São Paulo was spoken. This included grammar books, songbooks, and other texts that helped in the evangelization of the Indians. This production was one of the most efficient policies for managing multilingualism at the time, as shown by Mariani (2003: 77): "the codification made by the Jesuits represents a step in the process of translation, adaptation, and conversion of the pertinent meanings to the indigenous culture to the constitutive meanings of European and Christian culture." These policies spread the Catholic faith and influenced the behavior of the dominated peoples. The wider socio-historical context is summarized in the following passage:

In São Paulo, throughout the $17^{\text {th }}$ century, the Bandeirantes' performance in their search for the gold and precious stones mines stands out. In the Amazon, they sought to expel the Dutch invaders, secure Portugal's territory, and imprison as many people of the indigenous population as possible. In both regions, opposing interests confront the Jesuits, always favorable to the indigenous population, the colonists, whose most significant interest is the natives' enslavement, and the metropolis, for which the (Christianized) indigenous represent more subjects for the defense of the empire (Mariani 2003: 77).

In this context, then, the General Language is a central point of political disputes throughout the colony'. Moreover, conflicting interests, the necessity of unifying a large territory as well as competition from the Spanish also played a part. These issues will trigger more drastic measures taken by the Portuguese Crown with respect to the question of a general language, and actions to promote the Portuguese language as a political instrument to ratify Portugal's power will then begin.

\section{Pombaline interventions and their reflection in general languages}

The Amazonian General Language reached its maximum extent, from Maranhão to the border with Peru, by the half of the $18^{\text {th }}$ century. However, it was during the 
government led by Sebastião José de Carvalho e Melo, Marquis of Pombal, in the second half of the $18^{\text {th }}$ century, when he was Secretary of State for Internal Affairs of the Portuguese Kingdom, that the decline of the Amazonian General Language was more pronounced, given the official measures taken in favor of the Portuguese language.

It is worth mentioning the fact that such Pombaline measures were anchored in the Enlightenment ideals, which in the Portuguese case represented an enlightened despotism, reflected in several administrative, social, and economic reforms at the time. Regarding the actions taken against the languages spoken in the Colony, these reforms began to claim a central position for the Portuguese language in the provinces of Maranhão and Grão-Pará and Brazil. This imposition can be considered a historical-social factor that favored the eventual disappearance of the Amazonian General Language.

The metropolis' disputes with other European countries, such as Spain and the Netherlands, contributed to Pombal's actions, as, beginning with the $17^{\text {th }}$ century, the conception of the nation-language gained strength in Europe. The treaties of Utrecht (1715), Madrid (1750), and Santo Ildefonso (1777) recognized that each country had a right over the territory it had effectively occupied. The most significant dispute areas were Rio Branco and Alto Solimões, inhabited almost exclusively by indigenous peoples and, as the then Spanish governor declared on a demarcation trip, where there were "neither Portuguese, nor vestiges of any settlement of that nation" (Freire 2003).

The linguistic argument used by the Spanish governor was a primary criterion used to make the demarcations of the territory. In fact, "when the Treaty of Madrid seeks to delimit the borders of Portuguese America, the decisive criterion will be this: Portuguese America goes as far as Portuguese is spoken" (Hoornaert 1992: 170, in Freire 2003: 106).

We emphasize the fact that under Marquis of Pombal's command, language policies have a twist: the expansion and use of the Amazonian General Language, which in the previous century had been encouraged with the King's consent, started to be seen as a problem for the expansion and consolidation of the Portuguese kingdom in Grão-Pará and Maranhão. Marquis of Pombal brought the values of the Age of Enlightenment in his government and attempted to restructure the decadent European society of the old regime. This "modernization" passed through the sieve of the State, which, fed by the nationalist spirit, began to aim at centralization in all spheres. Such conduct was not only linked to the intention of exploitation the colony, but also to a relative sense of "care," a zeal for the land that would later serve as a refuge: As put by Carvalho (2003: 213), it was necessary "have zeal towards America, because the desire to protect Brazil has made it the government's apple of the eye. This, not only because it was the most significant supplier of wealth to the Portuguese Empire, but also because of the mystique it represented as a 'refuge' country".

One of the first declared language policies of Pombal was to sign a decree dated June 6,1755 , temporarily removing the power from the missionaries, who had begun to catechize and convince the population of the headwaters and streams to come settle in the villages of the middle and lower Rio Negro. The activities carried out by the missionaries until that date started to be coordinated by settlers, civil or military, who were also called "directors of the indigenous population" (Navarro 2012).

Two years later, on May 3, 1757, the minister of Portuguese King José I published the Directory of the Indigenous Population (a directory for the villages of the Indians of 
Pará and Maranhão): "This decision was accompanied by three drastic measures, capable of making it effective in the medium term: the revocation of the Missions' Rules, the expulsion of the Jesuits and the legal abolition of slavery for the indigenous population" (Freire 2003: 107). When the news arrived in the province, the then Governor Xavier de Mendonça, brother of the Marquis of Pombal, sent for an interpreter of the General Language to help announce the "good news" that had arrived from the metropolis, as we can see in the quotation:

"When the indigenous people were summoned to the sound of the trumpets, an officer of the Mendonça escort, an expert in Tupi language, informed them, insinuating that, for the future, they would live in other customs, other rules, and other laws" (Azevedo 1930: 319, in Freire 2003: 108).

Pombaline policies and other efforts for constructing a society on "Brazilian" lands in the period occurred via various means. The inclusion of the natives, after attempts at acculturation, for example, did not free them from forced labor, a labor that generated less profit than the African enslaved subject, but was still fundamental to the success of Portuguese colonization. In the case of language policies, colonial education measures did not spare the specificities of the languages of the indigenous population, which represented a living heritage, their oral culture, and which gave them a sense of the tribe, of the collective... of a civilization.

Although the declared language policies favored Portuguese over the General Language, speakers continued to use it mainly in communities further away from urban centers. It was only almost a century after the administration of Xavier de Mendonça and a few years after the unification of the two states (Brazil, and Grão-Pará and Maranhão), after the revolt known as Cabanagem ${ }^{5}$ that the number of general-language speakers decreased dramatically.

Cabanagem was the largest and most important popular movement in Brazil. That is, "it was an explosion of feelings of the poor masses, exploited for centuries, but not channeled to achieve economic and social transformations that could improve the lives of the most disadvantaged" (Navarro 2012: 247). Especially from 1832 through 1842, the cabanos and indigenous people from different linguistic backgrounds "used the General Language as an instrument of interaction, but in this case, communication was oral, because they were mostly illiterate" (Freire 2003: 73). It is essential to point out that the revolt left more than thirty thousand of Amazonian General Language speakers dead, drastically reducing the native speakers who knew the language.

In the $19^{\text {th }}$ century, from 1870 onwards, the influx of thousands of Portuguese-speaking northeasterners who arrived in the Amazon fleeing the drought and who were attracted by rubber exploitation in the region turned the Amazon General Language into a minority language. From the $19^{\text {th }}$ century onwards, the language was called Nheengatu, a term used by Couto de Magalhães who considered it to be the French or English of the

\footnotetext{
${ }^{5}$ The name Cabanagem refers to a type of hut used by the poorest people living along the waterways of northern Brazil.
} 
Amazon region, because it was understood "in all nations, even those that do not speak Tupi” (Freire (2003: 56, quoting Magalhães 1875: 16).

The richness of the Nheengatu language manifested at the phonological, lexical and syntactic levels, captivated scholars interested in the indigenous culture through the narratives part of the oral tradition materialized in different versions in a single language - Nheengatu. The aesthetics of this tradition was expressed in legends, myths, and stories of different peoples, a complex intangible heritage in an amalgam of cultures.

In the wake of the attempt to make the colony as Portuguese as possible, the creation of the Aulas Régias and the demand for Portuguese-speaking teachers, and the lack of structure in the teaching field, fuelled the process of disappearance of general languages. However, in the state of Grão-Pará and Maranhão, with an enormous territorial extension, such actions faced difficulties in implementation because the Amazonian General Language speakers who lived in the inlets and headwaters were protected by the labyrinths of the forest and rivers of the Amazon, resisting over time, while losing speakers in São Luís and Belém.

This discussion is intrinsically linked to the patrimonial bias since language can be understood as an ancestral heritage, always metamorphosed by present demands. It is in the multiplicity of communicative events that peoples recognize each other, coexist, and (re)build their culture. In this sense, in the face of colonialist impositions, languages can be understood as real cultural goods - a heritage. The specificity and identity conferred by language to small, peripheral groups, turn it into a factor of representativeness, based on belonging and recognition.

The process of linguistic colonization, resulting from the Pombaline policies and other guidelines aiming at the establishment of a "monolingual" Brazil in a multilingual territory, tried in one way or another to "silence" the linguistic and cultural diversity of the country. It could be said, perhaps, that both the indigenous peoples and the languages they spoke have suffered catechesis, i.e. were acculturated by a new model of society, imposed either by barter or by force. Speaking of the erasure of "particularities and cultural identities," Pereira (2017: 14) points to the marginalization of peoples who spoke minority languages. Pereira (2017: 14) further points out that "these groups are denied the rights to use and develop their mother tongues as well as to the attention of the State in the creation of mechanisms to guarantee the use of languages in public services of education and health, for example".

If one considers that language specificities also guarantee access to a group's heritage, such as legends, tales, myths, and symbols of an entire culture ${ }^{6}$, one can question the gravity of language policy in the Pombaline period for the shattering of indigenous societies.

\section{Conclusions}

In this paper, we sought to highlight the emergence and decline of general languages in colonial Brazil, anchoring our discussion in theoretical contributions from

\footnotetext{
${ }^{6}$ A topic for further research would be the approach of the topic of general languages starting from the notion of heritage since the linguistic dimensions also touch on issues of culture and identity.
} 
studies in language policies, namely notions such as the colonial language policy, language management, and the social history of speaking. It should be stressed that the present paper makes no claim to exhaustiveness, but is rather an overview of the many complex issues involved.

A note on the current reality of indigenous languages in Brazil is also in order at this point. As far as the specific case of Nheengatu is concerned, the language is still spoken today in the Rio Negro basin, in the city with the highest percentage of indigenous population in Brazil, having displayed remarkable resilience throughout its history since the Pombaline actions in the colonial period. A successful example of this resistance was the process that culminated in the officialization of Nheengatu, Tukano and Baniwa in the city of São Gabriel da Cachoeira in the state of Amazonas in 2002.

Although the General Language arouses the interest of researchers, teachers and activists, and the 1988 Federal Constitution guarantees the teaching and preservation of indigenous languages and cultures in Brazil, it is still necessary to promote and fight for indigenous peoples and their language rights, especially in Brazil's current economic and political context in which the ruling class is neglecting the rights of native peoples.

It is also worth mentioning Law 11.645/08, which regulates the compulsory teaching of Indigenous and Afro-Brazilian History and Culture. However, a question - and, at the same time, an issue for further research - remains: what are the real changes for linguistic diversity and its preservation that the Brazilian legislation guarantees and implements?

We also point out that the United Nations declared 2019 as the International Year of Indigenous Languages, and in that same year, in December, UNESCO declared the International Decade of Indigenous Languages (2022-2032). Added to this action is a proposal to include the indigenous languages spoken in the Brazilian Amazon part of humanity's tangible and intangible heritage (Pica et al. 2019).

These actions of revitalization, protection and safeguarding promote not only the knowledge of indigenous languages and cultures, but also show us the importance of these cultural artifacts, which enable speakers to learn and share knowledge and experiences in different dimensions of social life.

\section{References}

Argolo, W. 2016. As línguas gerais na história social-linguística do Brasil. PAPIA: Revista Brasileira de Estudos do Contacto Linguístico 26 (1): 7-52.

de Arnoux, E. N. 1999. Política lingüística: los contextos de la disciplina. In R. Bein, N. Blaisten \& L. Varela (eds.), Políticas lingüisticas para América Latina. Actas del Congreso Internacional, Buenos Aires, 26 al 29 de novembre de 1997, 13-23. Buenos Aires: Universidad de Buenos Aires, Faculdad de Filosofía y Letras. 1976. A cultura brasileira, part 3, A transmissão da cultura, $5^{\text {th }}$ edition. São Paulo: Melhoramentos/INL.

Bagno, M. 2018. Duas línguas, quantas políticas. In: P. F. Pinto \& S. Melo-Pfeifer (eds.), Políticas linguísticas em português, 24-40. Lisbon: LIDEL.

Baldauf Jr, R. B. 2004. Language planning and policy: Recent trends, future directions. Paper presented at the conference of the American Association of Applied Linguistics, 1-4 May 2004, Portland, 1-8. https://espace.library.uq.edu.au/view/UQ:24518

Bonacina-Pugh, F. 2012. Researching 'practiced language policies': Insights from conversation analysis. Language policy 11 (3): 213-234. 
Burke, P. 2002. História e teoria social. São Paulo: Unesp.

Cotrim, G. 2005. História Global: Brasil e Geral. São Paulo: Saraiva.

de Castilho, A. T. 1962. A lingual portuguêsa no Brasil (1). Alfa 1: 9-24.

de Castilho, A. T. 2008. A hora e a vez do português brasileiro. Museu da Língua Portuguesa. Museu da Língua Portuguesa-Estação da luz. https://www.museudalinguaportuguesa.org.br/wp-content/ uploads/ 2017/ 09/A-hora-e-a-vez-do-portugues-brasileiro.pdf Fausto, B. 2002. História do Brasil. 13. São Paulo: Editora da Universidade de São Paulo.

Fiegueira-Cardoso, S. \& da Silva Borges, A. 2020. As vozes da resistência: o caso da lingual geral amazônica. In J. C. Dias \& S. Figueira-Cardoso (eds.). Vozes nas margens: Estudos de língua e cultura sobre temas marginais dos países de língua portuguesa, 131-150. Warsaw: Instytut Studiów Iberyjskich i Iberoamerykańskich UW.

Freire, J. R. B. 2003. Da língua geral ao português: para uma história dos usos sociais das línguas na Amazônia. Rio de Janeiro: UERJ.

Lagorio, C. A. 2009. Léxico, dicionários e tradução no período colonial hispânico. Alea: Estudos Neolatinos 11 (2): 309-320.

Lobo, T., Machado Filho A. V. L. \& Mattos e Silva, R. V. 2006. Indícios de língua geral no sul da Bahia na segunda metade do século XVIII. In T. C. Freire Lobo, I. M. de Oliveira Ribeiro, Z. de Oliveira Novais Carneiro \& N. L. Fernandes de Almeida (eds.), Para a história do português brasileiro, 609-630. Salvador: EDUFBA.

Lucchesi, D. 2012. A diferenciação da língua portuguesa no Brasil e o contato entre línguas. Estudos de Lingüística Galega 4: 45-64.

Mariani, B. 2003. Políticas de colonização linguística. Letras 27: 73-82.

Mariani, B. 2004. Colonização linguística. Línguas, política e religião no Brasil (séculos XVI a XVIII) e nos Estados Unidos da América (século XVIIII). Campinas: Pontes.

Navarro, E. A. 2012. O último refúgio da língua geral no Brasil. Estudos Avançados 26 (76): 245-254.

Navarro, E. A. \& Tessuto Jr, E. 2016. Breve história da língua Tupi. Metalinguagens 3 (1): 25-35.

Ortiz-Osés, A. 2003. Hermenêutica, sentido e simbolismo. In A. F. Araujo \& F. Baptista (eds.), Variações sobre o imaginário: domínios, teorizações e práticas hermenêuticas, 93-139. Lisboa: Instituto Piaget.

Pereira, G. R. 2017. Quando língua é patrimônio? Políticas de patrimônio e de promoção da diversidade linguística no contexto do Inventário Nacional da Diversidade Linguística (INDL). MA dissertation Instituto do Patrimônio Histórico e Artístico Nacional, Rio de Janeiro.

Pica, P., Chomsky, N. \& Chomsky, V. 2019. Proposta para a inclusão de línguas indígenas da Bacia Amazônica brasileira como parte integrante do patrimônio material e imaterial da humanidade." Viva Lingua Viva. https://hal.archives-ouvertes.fr/halshs-02424725.

Prado Jr, C. 2008. História econômica do Brasil. São Paulo: Brasiliense.

Raymundo, G. M. C. 1998. Os princípios da modernidade nas práticas educativas dos jesuítas. MA dissertation. Universidade Estadual de Maringá.

Ribeiro, D. 1995. O povo brasileiro: a formação e o sentido do Brasil. São Paulo: Companhia das Letras.

Ricento, T. 2000. Historical and theoretical perspectives in language policy and planning. Journal of sociolinguistics 4 (2): 196-213.

Rodrigues, A. D. 1986. Línguas brasileiras: para o conhecimento das línguas indígenas. São Paulo: Edições Loyola.

Rodrigues, A. D. 1996. As línguas gerais sul-americanas. PAPIA: Revista Brasileira de Estudos Crioulos e Similares 4 (2): 6-18.

Schiffman, H. F. 1996. Linguistic Culture and Language Policy. London: Routledge

Spolsky, B. 2004. Language Policy. Cambridge: Cambridge University Press

Spolsky, B. 2009. Language Management. Cambridge: University Press.

Vieira, A. 2001. Sermões, vols. I and II. SãoPaulo: Hedra. 